\title{
Megatemplos evangélicos na experiência urbana ${ }^{1}$
}

\author{
Evangelical megachurches in the urban \\ experience
}

\section{Rita de Cássia Gonçalo Alves*1}

Palavras-chave: Megatemplos;

Serviços;

Consumo;

Escalas.

Keywords: Megachurches;

Services;

Consumption; Scales.

\begin{abstract}
Resumo: $O$ presente artigo traz uma abordagem conceitual sobre a relação simbólica da expressão cristã evangélica no urbano sob a forma de grandes templos, aqui tratados como megatemplos evangélicos. A metodologia de análise baseia-se no conteúdo de pesquisa etnográfica e revisão literária em perspectiva interdisciplinar. O fenômeno é apresentado em seus aspectos arquitetônicos e religiosos, e também sob o prisma da inovação e das iniciativas das gestões dos megatemplos, com a provisão de uma rede de serviços, projetos de caráter local, atrações culturais e sociais, que conformam essa atual vertente evangélica de convergência entre religião $e$ as ofertas $e$ demandas da vida mental e social na cidade. A presença dos megatemplos evangélicos tem, portanto, a finalidade de inserirse enquanto um referencial para a população urbana. As estratégias arquitetônicas, estéticas, econômicas e sociopolíticas seriam um diferencial dessa tendência, em que o megatemplo se apresenta como um modelo para as grandes igrejas que disputam o mercado religioso na atualidade.
\end{abstract}

\begin{abstract}
This article presents a conceptual approach on the symbolic relationship of evangelical Christian expression in the urban in the form of large temples, here treated as evangelical megachurches. The methodology of analysis is based on the content of ethnographic research and literary revision in an interdisciplinary perspective. The phenomenon is presented in its architectural and religious aspects, and also under the prism of innovation and the initiatives of megachurches management, with the provision of a network of services, local projects, cultural and social attractions, which conform this current evangelical trend of convergence between religion and the demands of mental and social life in the city. The presence of evangelical megachurches, therefore, has the purpose of insert itself as a reference for the urban population. The architectural, aesthetic, economic and socio-political strategies would be a differential of this trend, in which the megachurches presents itself as a model for the great churches that are disputing the religious market today.
\end{abstract}

\footnotetext{
${ }^{1}$ Recebido em 19/02/2020. Aceito em 14/04/2020

*1 Doutoranda em Planejamento Urbano e Regional pelo IPPUR-UFRJ, mestra em Comunicação Social pela PUC-Rio. E-mail: ritagoncalo@ufrj.br.
} 


\section{Introdução}

$\mathrm{E}$ ste texto procura dar uma contribuição às abordagens sobre a expansão do cristianismo evangélico nas cidades brasileiras sob uma modalidade específica: a implantação dos megatemplos - espaços monumentais de culto religioso acompanhados por um complexo de serviços. A formulação desta premissa parte de uma hipótese: os evangélicos ${ }^{2}$ têm investido na implantação de megatemplos ao invés de reproduzirem a utilização de espaços já prontos para que assim apareçam na cidade como modelos de referência em prosperidade e legitimidade da religião cristã evangélica. A lógica que fomenta esse empreendimento ambicioso é a da estratégia de urbanidade ${ }^{3}$, para o qual o megatemplo e seus serviços representam uma das "saídas" às problemáticas urbanas, aos contextos de ordem/desordem específicos das cidades.

\footnotetext{
${ }^{2}$ Ressalta-se que o cristianismo evangélico não é uma categoria homogênea. Oficialmente, a religião possui grupos divididos em três nomenclaturas adotadas pelo IBGE para fins de recenseamento e produção de demais dados estatísticos. São elas: a) evangélicos de missão: caracterizam a comunidade protestante resultante tanto da ação missionária norteamericana e inglesa como os protestantes que chegaram durante o fluxo imigratório dos séculos 19 e 20, vindos da Alemanha para o sul do país. Representantes desse segmento são, por exemplo, as igrejas Presbiterianas e Metodistas; b) evangélicos de origem pentecostal: englobam as que tiveram início no reavivamento místico e na atualidade do poder e dos dons do Espírito Santo, cujo sinal exterior era o falar em línguas estranhas (glossolalia) no primeiro quartel do século 20 nos EUA (pentecostais tradicionais). Essa categoria inclui, ainda, as igrejas oriundas do pentecostalismo originalmente brasileiro fundadas a partir de uma nova cosmologia das experiências místicas com o sagrado incluindo elementos sincréticos da religiosidade brasileira, com ênfase na teologia da prosperidade (mais conhecidas como "neopentecostais"); c) evangélicos não determinados: categoria que supostamente abarcaria as outras igrejas que fogem das nomenclaturas denominacionais tradicionais. Inclui também, na perspectiva de Mafra (2013), os frequentadores esporádicos do cristianismo evangélico, que compõem a religião a partir de uma circulação entre várias igrejas, o que ajuda a adensar e ampliar uma categoria alicerçada na noção de "vínculo congregacional frouxo" (MAFRA, 2013, p. 20). Para detalhes da classificação e composição evangélica no país, ver SIDRA - Sistema IBGE de Recuperação Automática - Dados da Amostra (2010).

${ }^{3}$ Para Lefèbvre, a realidade da cidade envolve um conjunto de problemas, que se entende por "problemática urbana". Esse espaço urbano é contradição concreta. O estudo de sua lógica e de suas propriedades formais conduz à analise dialética de suas contradições. Em suas palavras, "o urbano é um campo de tensões altamente complexo", no qual os teóricos buscam compreender "para onde o processo de urbanização arrasta a vida social" (LEFÈBVRE, 1999, p. 44). Frente a isto, a urbanidade se apresenta como "resposta" a tais contradições- um jeito de ser na cidade, uma forma de equacionar a ordem frente à desordem (PECHMAN, 2002). Urbanidade é um comportamento frente ao urbano, desempenho, atitude, maneiras; modos, métodos, atitude política. "Urbanidade gospel" é, portanto, o modo evangélico de oferecer uma "solução" às problemáticas urbanas.
}

Caderno Eletrônico de Ciências Sociais, Vitória, v. 8, n. 1, pp. 60-90, 2020. 


\section{Método}

Minha pesquisa etnográfica (de 2017 a 2020) adotou ferramentas como observação participante e coleta de dados primários, levantamento de dados em fontes de pesquisa (como secretarias municipais de urbanismo, arquivos públicos municipais e bases georreferenciadas) e revisão literária em perspectiva interdisciplinar nos campos do planejamento urbano, economia, arquitetura e sociologia, que colaboraram para a reflexão sobre esta questão.

0 interesse pela monumentalidade das igrejas evangélicas monumentalidade que aponta para obras de grandes dimensões e que se revela como uma celebração autorreferente do poder religioso no urbano - motivoume a desenvolver uma caracterização da categoria megatemplo. Nessa definição, considero que megatemplo (e sua nomenclatura sinônima megaigreja) é não só o espaço de culto religioso em edificações suntuosas e com ampla capacidade de agregação de fiéis, mas, especialmente, o lugar que concatena serviços e políticas sociais de diferentes naturezas, oferecendo em seu complexo diversas modalidades de amparo que, de alguma forma, vão de encontro à expectativa e demanda do fiel que é, também, cidadão metropolitano, acompanhando respostas singulares às carências presentes nos contextos de família, na saúde, no trabalho, nos negócios, nas formas de representação da vida (MAFRA \& ALMEIDA, 2009).

Essa linha de raciocínio sobre a presença de megatemplos evangélicos nas metrópoles considera $o$ fato de que apenas algumas correntes denominacionais históricas e pentecostais aplicam seu capital financeiro e de relações sociais para levantar essas imponentes fortificações. Isso me fez perceber que essas igrejas têm investido na produção de aparatos urbanoreligiosos atraentes, procurando levar adiante uma estratégia de inversão dos sinais convencionalmente instituídos no modo de apresentação do sagrado na metrópole. Devido a estas variáveis, é possível propor que a emergência de megatemplos na cidade seja vista sob uma perspectiva espacial e colocada dentro de um sistema de referência sociológico, qual seja: dialogar com as noções contemporâneas de pertencimento à vida urbana e a um novo estilo de apresentação do religioso no espaço público.

\section{Caracterização do objeto}

Minha descrição sobre megatemplos toma como referencial de análise os espaços Primeira Igreja Batista de Curitiba, no bairro do Batel, e o Templo da Glória do Novo Israel, da IURD em Del Castilho/RJ: como ocupam seu lugar em oposição ao ambiente secular; como eles, enquanto evocações do sublime, ajudam os crentes a lidar com os limites da subjetividade moderna, e, ainda,

Caderno Eletrônico de Ciências Sociais, Vitória, v. 8, n. 1, pp. 60-90, 2020. 
como estes funcionam enquanto centros comunitários na vida cotidiana urbana. Desta maneira, procuro considerar essas práticas em seus aspectos mais expressivos, de modo a apreendê-las em sua estratégia e no contexto da dinâmica urbana examinada ${ }^{4}$.

Tendo em vista a amplitude do fenômeno no cenário brasileiro, optei pelo estudo analítico de apenas duas igrejas considerando a validade das homologias estruturais do campo evangélico, nos termos de Bourdieu (1983). Ou seja, os atributos inerentes a este campo, o da monumentalidade cristã evangélica na forma de megatemplos, tendem a se organizar segundo a mesma lógica - que incluem projeto arquitetônico, diferencial estético, complexo de serviços podendo ser reproduzíveis em outros megatemplos, guardadas as suas proporções.

A escolha por estas denominações também foi baseada em alguns critérios seletivos. O Templo da Glória do Novo Israel, no Rio de Janeiro, e a Primeira Igreja Batista de Curitiba estão entre os primeiros megatemplos evangélicos projetados e edificados em metrópoles brasileiras na década de 1990, período que deu início à onda de edificação de megatemplos para fins estratégicos nas grandes cidades do país. Selecionei esses templos por possuírem características que enriquecem a perspectiva analítica do tema: a) estão em metrópoles diferentes e com contrastes específicos; b) são provenientes de correntes evangélicas distintas - uma pentecostal e outra de denominação histórica; c) possuem atuação em classes sociais diversas (abrangendo as camadas populares, a "nova classe média" e as camadas médias-altas; e d) adotam linguagens estéticas e discursivas únicas, embora apresentem afinidades. Ambas as igrejas mostram que, para o indivíduo, a razão não é suficiente para satisfazer as necessidades: é preciso recorrer à logica da fé.

\section{Contextos}

\section{Megatemplo e suas conexões na urbe}

De acordo com Susan P. Bratton, no curso da história da igreja cristã "edifícios com milhares de congregantes apareceram desde a antiguidade tardia, e espetaculares basílicas que datam do primeiro milênio do cristianismo ainda estão de pé" (BRATTON, 2016, p. 83). A planta de Hagia Sophia, por exemplo - agora uma mesquita em Istambul, na Turquia - foi esboçada para contemplar até 20.000 fiéis. Igrejas norte-americanas de mais de 2.000

\footnotetext{
${ }^{4}$ A dinâmica urbana examinada considerou os bairros de Del Castilho (RJ), Batel (Curitiba) e zonas adjacentes nas quais as igrejas pesquisadas têm atuação relevante. Neste sentido, a pesquisa evidencia relatos amostrais das experiências evangélicas nessas metrópoles.
}

Caderno Eletrônico de Ciências Sociais, Vitória, v. 8, n. 1, pp. 60-90, 2020. 
membros foram pastoreadas por figuras importantes, como os abolicionistas Charles Finney e William Joseph Seymour, e tantos outros oradores afroamericanos reconhecidos nacionalmente pastorearam grandes igrejas desde 0 início do século XIX (BRATTON, 2016). Na década de 1920, quando muitas denominações não permitiam que a mulher assumisse o púlpito, a pastora Aimee Semple McPherson "liderou o Angelus Temple de 5.400 lugares em Los Angeles, Califórnia, e fundou a Igreja do Evangelho Quadrangular" (BRATTON, 2016, p. 85).

Fornecendo orientação para os movimentos abolicionistas no Pentecostalismo, as primeiras megaigrejas norte-americanas foram localizadas, em grande parte, nas áreas centrais das principais cidades. Neste sentido, a emergência de grandes igrejas cristãs acompanha o processo de urbanização nas cidades norte-americanas que procuram expandir seus papéis econômicos e influência cultural (RUIZ, 2005).

Cidades como Los Angeles, Dallas, Houston e Chicago começaram como centros regionais, facilitando o fluxo de bens comerciais, intermediando a colheita de recursos agrícolas ou naturais ou servindo como capital do estado. À medida que as redes de transporte e vendas melhoram, esses centros "se transformam em metrópoles e adquirem filiais e sedes regionais de empresas nacionais e, posteriormente, sedes multinacionais, filiais de empresas europeias e asiáticas e uma população na casa dos milhões" (RUIZ, 2005, p. 735).

Junto a esses centros estão as megaigrejas cristãs, muitas das quais ainda têm congregações ativas. As megaigrejas norte-americanas "surgiram em toda a extensão de grandes metrópoles" (BRATTON, 2016, p. 87), cuja combinação de economias tecnológicas aceleradas e expansão maciça nos subúrbios fizeram de estados como Texas e Califórnia os epicentros do fenômeno das megaigrejas, com prevalência de denominações evangélicas (BRATTON, 2016, p. 87). Essas instituições não apenas fornecem insights sobre a paisagem dos megatemplos atuais, mas também oferecem um registro do quanto os megatemplos, desde sua origem, já pressupunham o interesse em serem coadjuvantes no ordenamento municipal (BRATTON, 2016).

Tal exploração das oportunidades e pressões da urbanização servem como comparação para a observação dos cruzamentos entre religião e metrópole. Dallas, Houston, Los Angeles e Chicago são regiões metropolitanas onde se localizam algumas das maiores e mais antigas megaigrejas dos Estados Unidos - as quais, além de monumentais, estão entre as mais bem-sucedidas em termos de atração de membros.

Caderno Eletrônico de Ciências Sociais, Vitória, v. 8, n. 1, pp. 60-90, 2020. 
Cito como famosas megachurches ${ }^{5}$ norte-americanas a Lakewood Church (Houston-Texas), do pastor Joel Osteen; a Willow Creek em Chicago, liderada pelo televangelista Bill Hybles; a Saddleback Baptist Church (Califórnia), em que Rick Warren é o pastor principal; a Cristal Cathedral ${ }^{6}$, situada em Garden Groove, na Califórnia, projetada pelo famoso arquiteto Philip Johnson, sendo considerada uma das mais importantes referências na composição de megatemplos religiosos.

Figura 1: Fachada da Cristal Cathedral, Califórnia/EUA.

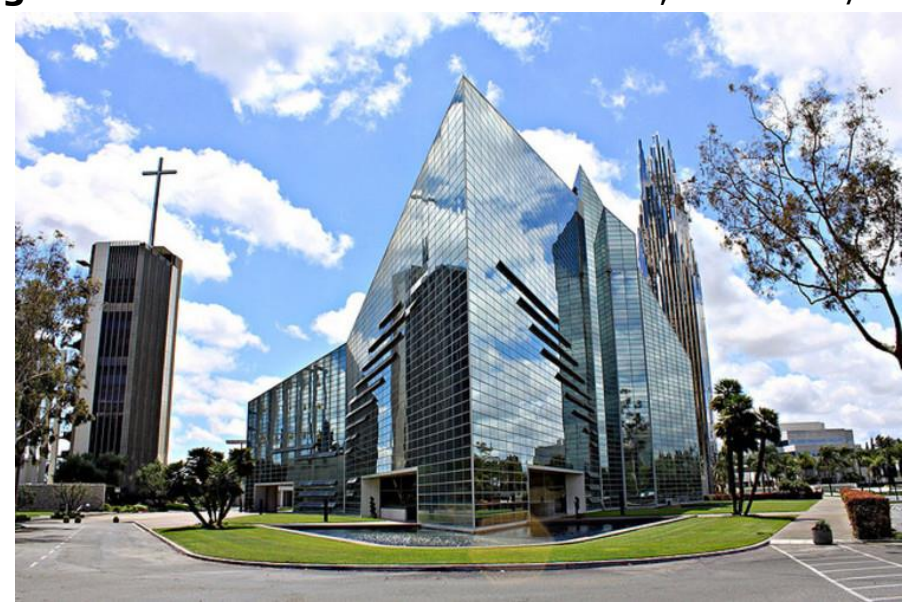

Fonte: ArchDaily (2013) ${ }^{7}$.

Figura 2: Campus South Barrington da Willow Creek Church, Illinois/EUA.

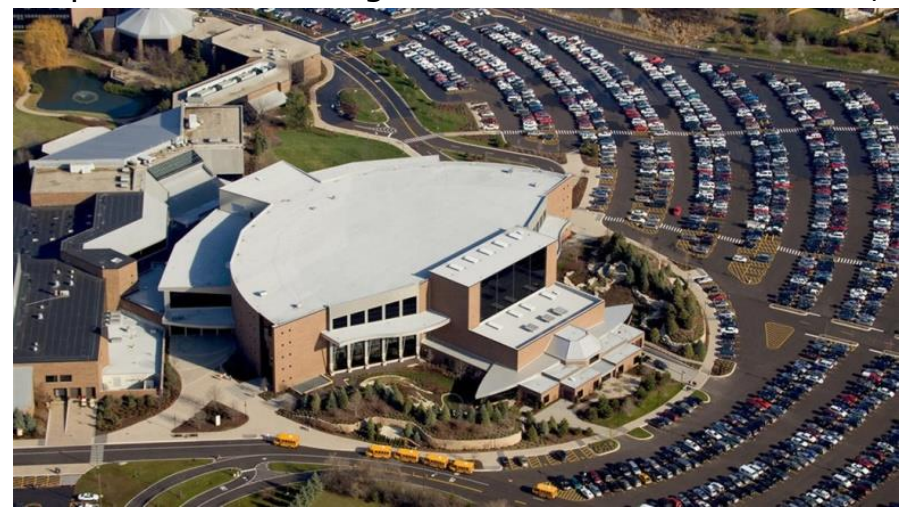

Fonte: Willow Creek Community Church $(2020)^{8}$.

\footnotetext{
5 "Megachurches" é a tradução do termo "megatemplo" para o inglês, e o modelo de funcionalidade da megachurch e do megatemplo brasileiro encontra muitas similaridades, como veremos a seguir.

6 A Cristal Cathedral nasceu em 1977, encomendada por Robert Schuller, pastor da congregação protestante Ministério Catedral de Cristal, braço da Igreja Reformada da América. Atualmente ela foi transformada em um templo mais próximo da identidade cristã católica.

7 Disponível em: https://www.archdaily.com.br/br/01-151061/o-renascimento-da-catedralde-cristal-de-philip-johnson. Acesso em: 22 jan. 2020.

${ }^{8}$ Disponível em: https://www.willowcreek.org/en/locations/south-barrington. Acesso em: 11 mai. 2020.
}

Caderno Eletrônico de Ciências Sociais, Vitória, v. 8, n. 1, pp. 60-90, 2020. 
Figura 3: Paisagem da Lakewood Church, Houston/EUA.

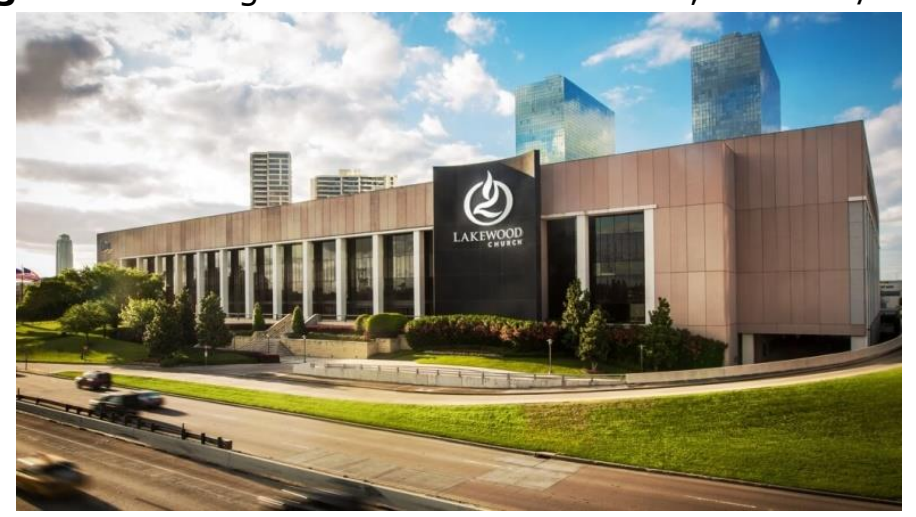

Fonte: Lakewood Church (2020) ${ }^{9}$.

\section{O megatemplo evangélico brasileiro}

Em relação ao Brasil, o megatemplo enquanto experiência evangélica urbana é uma tendência que vem sendo avaliada pelos pastores no começo dos anos 1980 nessa interlocução com as megachurches norte-americanas (THUMMA \& TRAVIS, 2007). Por aqui, o megatemplo aparece no trânsito entre década de 1990 para o ano 2000, e passa a ser reproduzido em diferentes cidades a partir de então.

As transformações estruturais da sociedade brasileira - urbanização, industrialização, monetização, secularização da vida, entre outros fatores indubitavelmente tiveram uma influência na transição religiosa do país e na expansão das denominações do cristianismo evangélico. Com o aumento do poder econômico de alguns estratos da população brasileira, o qual possibilitou certa mobilidade social de indivíduos da classe D para as chamadas classes $C$ e B nos anos 2003 em diante (NERI, 2019), verificou-se que os efeitos dessa transformação econômica também se fizeram presentes nas igrejas evangélicas. A estimativa por meio de dados estatísticos oficiais, como os do IBGE (2017 apud ALVES et al., 2017) mostra que, até 2040, a previsão é de os evangélicos alcancem $43 \%$ do total da população. Sendo assim, a competição interurbana no espaço fez com que muitas comunidades evangélicas concorressem entre si, o que implicou "estratégias competitivas e um sentido

\footnotetext{
${ }^{9}$ Disponível em: https://www.lakewoodchurch.com/contact. Acesso em: 05 abr. 2020.
} 
ampliado de consciência daquilo que torna um lugar especial e lhe dá vantagem competitiva" (HARVEY, 1996, p. 247).

Pode-se dizer que este cenário - o de aumento do percentual de evangélicos nas grandes cidades e a mobilidade socioeconômica de cristãos evangélicos para as camadas C e B - autorizou a consolidação dessa tendência à criação de megatemplos evangélicos no contexto brasileiro, onde diferentes correntes evangélicas - desde as tradicionais até as neopentecostais e alternativas - aderiram à construção de megatemplos enquanto modelo de expressão da força e hegemonia de suas denominações.

O megatemplo sintetiza a complexificação de um processo de estratégia multiterritorial do cristianismo evangélico contemporâneo, uma vez que ele inclui: i) a vivência de distintas práticas sociais, deixando explícita uma "acepção de poder simbólico e de apropriação do lugar" (HAESBERT, 2007, p. 20) e; ii) a construção de intervenções e serviços que dão origem a múltiplas formas de disputa, isto é, de situações em que "o Estado partilha com os evangélicos atribuições e competências que até então eram de sua exclusiva responsabilidade" (RUA, 2014, p. 211), onde os megatemplos assumem a autoprovisão dos serviços sociais.

Antes de tudo é preciso lembrar o quanto a religião evangélica tem se aproximado das características de um modelo de sociedade e de politica neoliberal. Tanto 0 neoliberalismo ${ }^{10}$ quanto 0 cristianismo evangélico contemporâneo têm sido performados por uma proposta de individualização dos esforços, diminuição das atribuições e competências do Estado, um "modo de produção verticalizado e expansivo, autorregulação dos mercados, resolução de problemas sociais centrados na busca da eficácia e do compromisso" (RUA, 2014 , p. 209). Uma modalidade de ser e estar na cidade que integra circuitos do modo de produção, circulação e consumo em um único espaço, na medida

\footnotetext{
10 Utilizo a compreensão proposta por Dardot e Laval (2016) sobre o conceito de "neoliberalismo" enquanto pensamento político ora dominante na sociedade atual. Para os autores, o neoliberalismo é uma forma de governança e de intervenção que depende crucialmente de uma ação estatal abrangente, pois, não o move a velha crença na autorregulação espontânea do mercado, mas uma nova que reclama o suporte estatal constante para que a "livre iniciativa dos agentes sociais" prospere ainda no mundo contemporâneo. Esta forma visa reconstruir não apenas as instituições e as políticas econômicas, mas também a subjetividade das pessoas para torná-las mais adaptadas e mais adequadas ao capitalismo globalizado - entendido este como um modo de organização social característico e um estágio de desenvolvimento histórico. Nesse sentido, definem o neoliberalismo "como o conjunto de discursos, práticas, dispositivos, que determinam um novo governo dos homens segundo o princípio universal da concorrência abrangente" (DARDOT \& LAVAL, 2016, p. 41), e isso casa com as iniciativas do cristianismo evangélico atual, bastante centradas nos esforços do indivíduo moderno, no governo dos homens a fim de torná-los ajustados, combinados às emergências do capitalismo globalizado.
}

Caderno Eletrônico de Ciências Sociais, Vitória, v. 8, n. 1, pp. 60-90, 2020. 
em que o neoliberalismo age, também, como um aglutinador da acumulação de capital.

Neste sentido, quero chamar atenção para a maneira como o discurso neoliberal nas igrejas evangélicas alcança outras dimensões do processo de metropolização ${ }^{11}$ do espaço, para o qual o megatemplo se caracteriza como um empreendimento de forma arquitetônica que copia modelos de sucesso internacional - em especial o modelo norte-americano das megachurches. Refere-se, assim, a um espaço qualitativo e dinamizado, um elemento de marketing estratégico da religião, pois se configura não apenas como uma ocupação espacial, mas também como um equipamento urbano, cujo aspecto mais análogo ao capitalismo corresponde à oferta de diferentes modalidades de serviços - sociais, culturais, educacionais e de entretenimento - individuais e coletivos.

Sendo este um fenômeno cada vez mais recorrente na morfologia urbana, devemos pensar: o que caracteriza a produção dos megatemplos que combina com certas maneiras de a igreja aparecer na cidade?

\section{O modelo mental do megatemplo evangélico}

O megatemplo se apresenta atualmente como um dos principais referentes de produção de um espaço plural elaborado por igrejas evangélicas fortemente organizadas. Minha pesquisa etnográfica permitiu identificar o megatemplo como o lugar de culto evangélico que condensa um conjunto de atividades de consumo, de produção de cultura e políticas sociais direcionadas a seus usuários. Os megatemplos caracterizam-se por projetos suntuosos, cuja arquitetura transita pelas releituras entre os estilos neoclássico ou modernista. É possível mensurá-lo não apenas por suas dimensões físicas, com santuários que comportam até 10 mil pessoas ou mais, mas também (e especialmente) por sua relação a outros serviços oferecidos. Neste sentido, o megatemplo evangélico caracteriza-se como um espaço construído que condensa formas de fazer, pensar e agir do universo evangélico, qual seja: traduzir uma religião que produz sentidos de prosperidade e bem-estar social na cidade.

Reuniões que ocorrem nos sete dias da semana, em todos os turnos, são uma das características mais fundamentais do megatemplo. E, para garantir

\footnotetext{
${ }^{11}$ Neste sentido, a metropolização do megatemplo enquanto espaço religioso-urbano marca o atual momento de organização das grandes igrejas, em que elas incorporam algumas características anteriores - por exemplo, evangelização a grupos urbanos específicos - e, ao mesmo tempo, desenvolvem outros modelos de práticas espaciais, como ações sociais, culturais e de saúde organizadas em conjunto com secretarias municipais e estaduais. A metropolização do espaço - neste caso operada em parceria com os megatemplos contribui, num sentido amplo, para "transformar as dinâmicas espaciais urbanometropolitanas em diferentes escalas territoriais" (Cf. FERREIRA; RUA; MATTOS, 2014).
}

Caderno Eletrônico de Ciências Sociais, Vitória, v. 8, n. 1, pp. 60-90, 2020. 
novos conteúdos, nesses espaços são oferecidos serviços como visitas guiadas, exposições, atividades sociais, desportivas e culturais, serviços de saúde e várias outras programações até então atípicas num templo religioso. Sendo assim, o megatemplo evangélico trabalha com o capital de relações sociais e de consumo, abrindo espaço a novos territórios híbridos, com equipamentos que vêm aumentar suas potencialidades comerciais.

A inserção na estrutura social é pauta fundamental na agenda de pastores, lideres e gestores dos megatemplos, para que o equipamento urbano tenha uma posição ativa e reconhecida no entorno em que se insere e nas regiões periféricas. Para tanto, aplicam uma espécie de reprodução de suas ações por meio do modelo multi-site ${ }^{12}$, que se constitui no conjunto da ideia de megatemplo - a sede arquitetônica principal mais uma filial (ou "igreja irmã") com o mesmo perfil litúrgico, teológico, estético, só que instalado em outro bairro da cidade e voltado para alcançar as camadas periféricas. O multi-site é uma forma de a grande igreja estar presente na periferia, estimulando os indivíduos a um padrão de crescimento, prosperidade, empreendedorismo pessoal.

O modelo mental do megatemplo se constitui, portanto, em uma igreja que representa a realidade externa de demandas e interesses de uma grande metrópole (THUMMA \& TRAVIS, 2007). O conceito de modelo mental do megatemplo foi elaborado por Scott Thumma e Dave Travis (2007), mentores da Leadership Network - empresa de consultoria em liderança para pastores e igrejas localizada em Dallas, Texas/EUA. Esse mecanismo do modelo mental enquanto método para explicar o funcionamento ou a gestão de um megatemplo trata-se de uma das formas mais utilizadas por grandes lideranças evangélicas para interpretar os acontecimentos em volta e representar o alcance transformador que a religião evangélica pode ter no espaço.

Quando igrejas e pastores interessados pelas questões da cidade adotam o modelo mental do megatemplo, frequentemente tomam-se medidas práticas que aumentem a probabilidade para que ele cresça de fato. Algumas dessas etapas práticas incluem seleção geográfica estratégica e compra de terrenos de grandes proporções, construção de múltiplos prédios, adaptáveis, com plano

\footnotetext{
12 Multi-Site Church ou Igreja Multi-Site significa uma nova modalidade de estruturação, organização e administração tanto do crescimento como da expansão ao alcance evangelístico. A igreja multi-site é aquela que se reúne, simultaneamente, em diversos locais sem deixar de ser uma única igreja local, independentemente de sua linha teológica e/ou denominacional. O mesmo modelo de liturgia de culto e oferta de serviços é oferecido em diferentes bairros da cidade e também no alcance via redes sociais - como canais de streaming e aplicativos de celular, como WhatsApp. Os serviços da igreja multi-site têm sido uma estratégia ministerial sedutora aos líderes pastorais brasileiros e suas igrejas locais. Cf. OLIVEIRA (2013).
}

Caderno Eletrônico de Ciências Sociais, Vitória, v. 8, n. 1, pp. 60-90, 2020. 
explícito para expansões em estágios, instalações voltadas para programações e atividades, entre outros itens que indicam expectativa de crescimento. 0 modelo mental do megatemplo é baseado nas seguintes etapas:

Figura 4: Modelo mental do megatemplo evangélico.

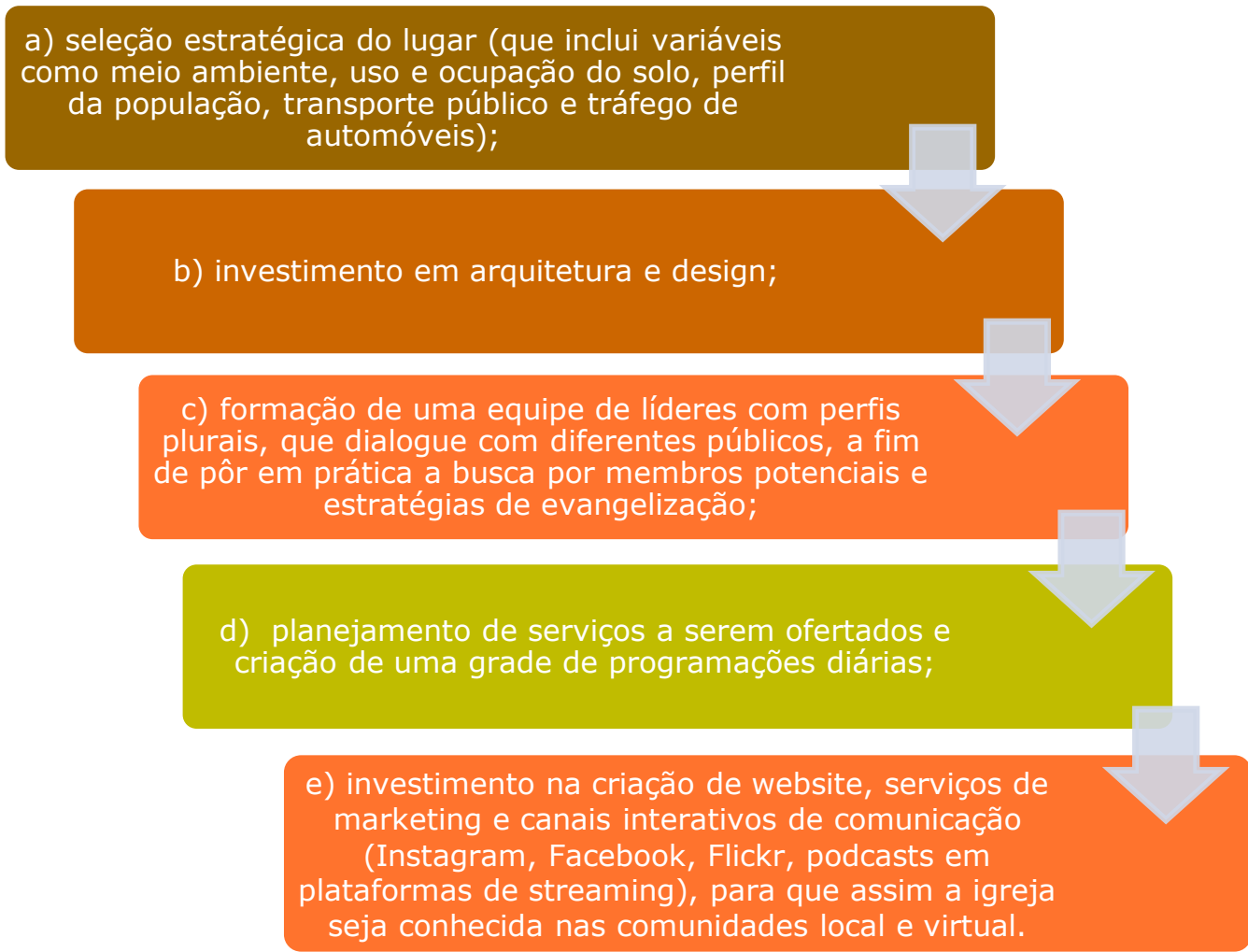

Fonte: Thumma e Travis (2007), adaptado pela autora para o caso dos megatemplos brasileiros.

Para que esse modelo mental seja posto em prática de maneira mais eficaz, os evangélicos contam com consultorias especializadas em liderança estratégica, crescimento de igrejas e aumento da audiência de fiéis para implantação dos megatemplos. O público-cliente das consultorias é formado, majoritariamente, por pastores e sua equipe de lideranças que, juntos, vão entender que a "melhor" igreja é aquela que cresce progressivamente em termos de número de fiéis, capital financeiro e capital simbólico. Esse tipo de management não é novo no meio evangélico; existe desde finais dos anos 1990 e surgiu nos Estados Unidos, por meio de instituições como City to City ${ }^{13}$, Generis $^{14}$, Acts29 Global $^{15}$, além da Leadership Network ${ }^{16}$. Seus líderes são pessoas de formação acadêmica e vivência em diversos países do mundo, que detêm um conhecimento empírico para oferecer uma paisagem de como o

\footnotetext{
${ }^{13}$ https://www.redeemercitytocity.com/. Acesso em: 28 jun. 2019.

14 https://generis.com/. Acesso em: 28 jun. 2019.

15 https://www.acts29.com/. Acesso em: 28 jun. 2019.

16 https://leadnet.org/. Acesso em: 28 jun. 2019.
}

Caderno Eletrônico de Ciências Sociais, Vitória, v. 8, n. 1, pp. 60-90, 2020. 
megatemplo pode atuar na sociedade. Nomes como Timothy Keller, Jay Bauman e Rick Warren estão entre os principais expoentes na paisagem global de implantação e desenvolvimento de megaigrejas.

No que tange ao público a ser captado para o megatemplo, percebe-se que há um interesse de acolherem um número proporcional de mulheres e homens, casais e solteiros, seniores, crianças, brancos, pretos e afrodescendentes, imigrantes - ou seja, toda sorte de diversidade de pessoas, para transmitir a imagem de uma igreja atual e dinâmica.

Por sua vez, no que corresponde ao mercado religioso do megatemplo, este é constituído pela dinâmica entre três componentes analiticamente distinguíveis: os "produtos" comercializados; os agentes que projetam, desenvolvem, "manufaturam" e distribuem os produtos; e os "consumidores" dos produtos (USARSKI, 2012). O vigor das igrejas evangélicas em se adaptarem, atendendo nichos mercadológicos, destaca que estas agências mostram "características empresariais de prestação de serviços ou de oferta de bens de religião" (MARANHÃO FILHO, 2010, p. 209). Para o empreendimento religioso, portanto, é necessária uma concepção de mercado não apenas como lugar de troca de mercadorias, mas como parte de interações socioculturais mais complexas. A não satisfação das necessidades dos públicos presente e potencial representa a perda deste para o concorrente, alimentando o rodízio ou trânsito em busca do sagrado.

As igrejas que participam do mercado religioso na atualidade buscam oferecer um ambiente em que as sensações de inclusão, pertencimento e de envolvimento com o universo divino e social sejam contempladas. Para tanto, apostam na satisfação dos anseios dos/as crentes consumidores/as, oferecendo bens que simbolizam sentimentos de felicidade, prosperidade, inclusão e sucesso. Este consumo possui uma "ética romântica" (CAMPBELL, 2002), orientada pela busca de satisfações em níveis materiais, subjetivos e espirituais. Os megatemplos enquanto agências religiosas produtoras de sentido oferecem, cada vez mais, "mercadorias" mágico-religiosas capazes de desencadear sensações prazerosas frente à possibilidade da realização da prosperidade abrangente. Neste sentido, o ato de comercializar não se constitui algo externo à fé.

Observemos como os principais nichos estratégicos propostos pelo megatemplo evangélico colaboram às crescentes demandas oriundas nas metrópoles, e como seus equipamentos de entretenimento e consumo fortalecem o movimento de fiéis nessas estruturas.

Caderno Eletrônico de Ciências Sociais, Vitória, v. 8, n. 1, pp. 60-90, 2020. 


\section{Estratégias espaciais e de governança do megatemplo}

\section{Escala}

O geógrafo Neil Smith (2000) introduziu a categoria de "políticas das escalas" enquanto processos sobre os quais se reconfiguram, de forma articulada, o poder e o território. Em tal contexto, a ideia de escala espacial procura demonstrar que novas formas organizacionais e novas modalidades de atuação são construídas para o enfrentamento de uma "crise" no padrão de reprodução econômica e social. Escala aqui denota a "extensão espacial dentro do qual os próprios atores entendem se mover" (WILFORD, 2012). Com isso, é possível observar que a escala espacial da formação dos megatemplos urbanos procuram engendrar suas próprias atividades, tarefas ou operações, de forma que Ihes permitam exercer influência no território. A ideia de grandeza não vem unicamente da arquitetura monumental da megaigreja, mas especialmente de um mix do desejo dos pastores em crescer e dos resultados de experiências que vêm de fora.

$\mathrm{Na}$ economia de escala, a megaigreja consegue se sustentar pelo superávit que ela tem em dízimos e serviços. O processo escalar relacionado ao aumento dos membros, dos dízimos e das práticas de fidelização cria, por conseguinte, uma economia de aglomeração, e, por isso, a igreja consegue crescer. Nestes termos, o megatemplo possui maior capacidade de ação devido a essa economia de escala que ele empreende.

\section{Estética e monumentalidade}

Surge como tendência atual entre os megatemplos evangélicos recorrerem a estilos arquitetônicos neoclássico (recuperando a antiguidade greco-romana, com grandes colunas e abóbadas) ou modernista (com design retilíneo e formas funcionalistas). Quanto à composição paisagística, muitas denominações investem em jardins adornados com pedras, oliveiras, tamareiras e outras árvores especiais. A volumetria das edificações é geralmente legível no tom das vias urbanas - algumas delas ocupam mais de um quarteirão. No interior do santuário, a composição de diferentes luzes aliadas ao potente tratamento acústico, às confortáveis poltronas, e aos estímulos estéticos, sonoros e visuais permitem que o visitante experimente algo próximo da sensação de transcendência.

O conforto físico e estético proposto pelos megatemplos projeta-se, portanto, como uma espécie de "oásis" em meio aos turbilhões socioemocionais que vivemos nas grandes cidades. Ao aproximar questões de bem-estar emocional e riqueza material, os templos-monumentos difusos pelo Brasil

Caderno Eletrônico de Ciências Sociais, Vitória, v. 8, n. 1, pp. 60-90, 2020. 
parecem estar em sintonia com os desafios do mundo contemporâneo e da vida mental na metrópole.

\section{Economia}

Noutro vértice do fenômeno, temos a sustentação econômica dos megatemplos na produção de um ambiente de consumo, o que implica perceber qual tem sido sua capacidade de investimento para expandir uma série de atividades que respondem a uma demanda de interesse mais geral. Uma tendência que os megatemplos têm adotado para isso é promover um ajuste espacial do que seja a ideia de um templo evangélico, transformando seu ministério em uma marca ${ }^{17}$, ou seja, um serviço que é $(A)$ distinto do que outros poderiam fornecer; (B) facilmente reconhecível pelas suas características particulares; e (C) exclusivamente fornecido a um público particular.

Segundo David Harvey (2005), uma das dimensões do ajuste espacial é atualizar as demandas do ambiente construído dada a centralidade do território no espaço urbano, coadunando-o com as formas capitalistas mais avançadas. Serviços que antes não existiam passam a aparecer, requeridos pela necessidade de acumulação no circuito primário. As formas pretéritas dos espaços de culto evangélicos dificultavam a constituição de um consumo aliado à modernidade. Neste sentido, coube aos megatemplos modernos atualizarem o ambiente construído para melhor cumprir uma função social. Novos espaços e relações espaciais são produzidos para dar vazão aos imperativos da acumulação de capital. A ideia do megatemplo possibilita, então, o funcionando de uma miríade de ativos financeiros, cuja circulação do valor é fragmentada em diferentes escalas.

Destacamos como modelo exemplar desse tipo de ajuste espacial os serviços de lojas, restaurantes, negócios voltados a entretenimento, habitação, centros culturais, ateliês de moda e artes presentes nos megatemplos evangélicos - estes últimos oferecendo roupas e acessórios idênticos àqueles usados por pastores, pastoras, líderes ou ícones do mercado fonográfico ligados às denominações destes santuários. Também é frequente o consumo de

\footnotetext{
${ }^{17}$ Mais adiante cito exemplos de como megatemplos evangélicos adquirem uma marca no território por fornecerem serviços distintos do que outras igrejas oferecem. Em Del Castilho/RJ, o Templo do Novo Israel da IURD é venerado pelas réplicas dos signos de Jerusalém, como o Muro das Lamentações e a maquete da cidade de Jerusalém nos tempos de Jesus, o que garantiria uma autenticidade singular da experiência mística nesse megatemplo evangélico. Já na PIB Curitiba, os vitrais e a beleza estética no interior da igreja causam nos visitantes uma especial sensação de transcendência meditativa, de contato com o sagrado. Esses aspectos são ainda potencializados quando da realização de espetáculos, como o Nataleluia em dezembro, que mobiliza toda a capital curitibana. Todas essas referências fortalecem o aumento das visitações nesses espaços, aumentando, consequentemente, o fluxo ao consumo dos produtos e serviços oferecidos nesses locais.
}

Caderno Eletrônico de Ciências Sociais, Vitória, v. 8, n. 1, pp. 60-90, 2020. 
materiais impressos e digitais ligados ao ordenamento da vida espiritual, familiar e financeira. Tudo isso caracteriza um consumo com vistas a materializar um sentido cultural, estético e simbólico de referentes legítimos, dimensões nas quais o presente modelo de acumulação no meio evangélico está fortemente imbricado.

\section{Sociopolítica}

Quanto ao aspecto sociopolítico percebe-se que os megatemplos evangélicos administram hoje certas funções que se acreditou serem do Estado - como o cuidado com a saúde, educação, esportes, entre outros -, ministrando certas demandas individuais que passam a ser tratadas como coletivas.

Figura 5: Alguns exemplos das escalas de atuação e consumo do megatemplo evangélico.

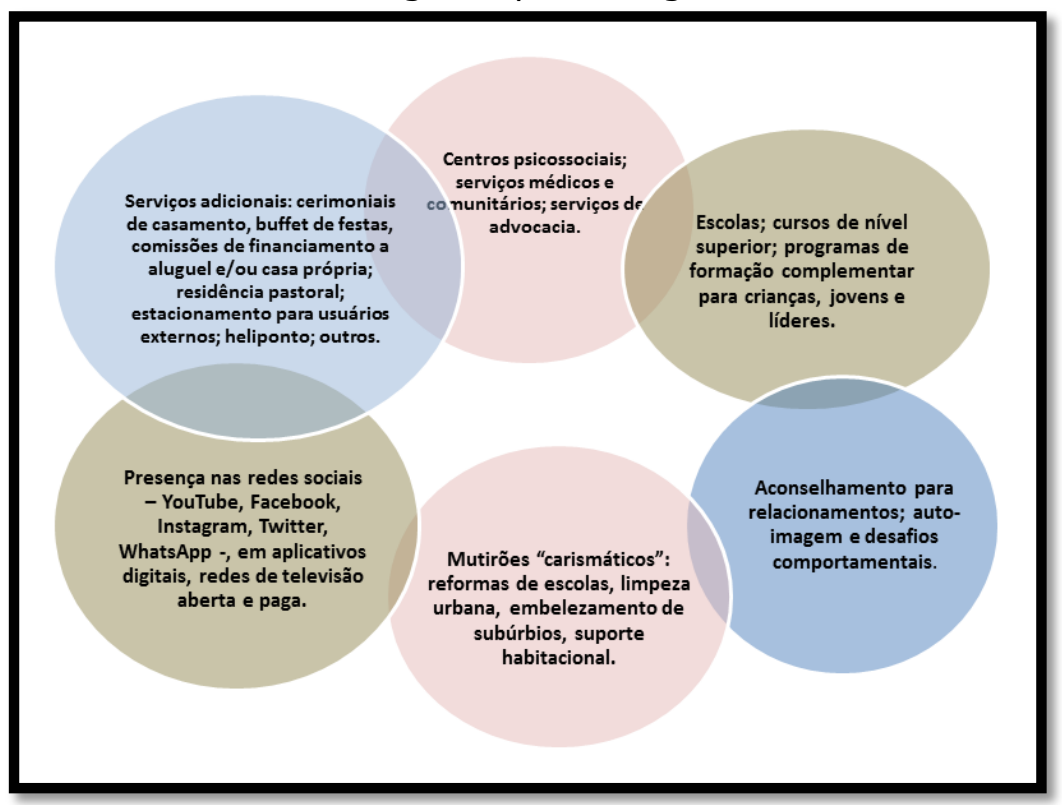

Fonte: WILLFORD (2012), adaptado pela autora para o caso dos megatemplos brasileiros.

Os megatemplos investem em um amplo leque de possibilidades de cidadania que vai muito além do âmbito religioso. Ação social, educação, música, esportes, artes, cuidados com a saúde, amparo a deficientes físicos, financiamento ao aluguel e à casa própria, bem-estar nos relacionamentos tudo isso está dentro de um guarda-chuva mais amplo que engloba o que seja a prosperidade e dignidade política dentro da teologia cristã. Destacamos, ainda, a importância dada pelos megatemplos de promover o encontro, de as pessoas se conhecerem, vencerem a solidão, criarem grupos. O objetivo dessas programações e formatos de ação política é multiplicar as formas de atendimento e as chances de encontro, oferecendo novas possibilidades de

Caderno Eletrônico de Ciências Sociais, Vitória, v. 8, n. 1, pp. 60-90, 2020. 
coesão social. Busca-se valorizar uma segmentação da comunidade, na qual cada um participa da unidade espacial, religiosa e cultural.

Essas ações podem ser entendidas como estratégias políticas de inclusão dos fiéis a um determinado exercício de "civismo". O conceito também alimenta a noção de comunitarismo18: "práticas que atendem ao apelo das virtudes cívicas, às metas comuns e à responsabilidade coletiva" (REIS, 1998, p. 40). A função dos megatemplos se insere nesses processos como um conjunto de atos de responsabilidade social, através dos quais tratam de participar dos arranjos da produção e da circulação de práticas de bem-estar social e de fortalecimento do comum. Todavia, esta vivência comum parte da ideia de que há um público delimitável e corporativo ${ }^{19}$ - os evangélicos usuários do megatemplo e suas redes - a quem se confere o reconhecimento de serem, estes, "sujeitos de direitos".

A incorporação dessa nova ética corporativa da responsabilidade social ao modelo religioso corrobora a tese de que os mecanismos institucionais na ordem política moderna nunca estão confinados dentro dos limites do que se chama formalmente de Estado. Michel-Rolph Trouillot (2006) defende que a construção analítica do Estado não está restrita apenas ao aparelho estatal. Para ele, o poder do Estado "não tem fixação institucional em bases teóricas ou históricas"; neste sentido, seus efeitos - isto é, seus processos e práticas, "nunca são obtidos apenas através de instituições nacionais ou em locais governamentais" (TROUILLOT, 2006, p. 126). Neste sentido, certas ordens que eram tidas exclusivamente como sendo do Estado se mantêm por meio da criação de outros mecanismos institucionais, o qual Trouillot chama de "efeitos de Estado". Sob essa ótica dos efeitos de Estado, a igreja atua enquanto mediador $^{20}$ da burocracia estatal, e os vínculos formados pela oferta de

\footnotetext{
${ }^{18}$ Para o comunitarismo - que tem entre seus principais expoentes Charles Taylor, Michael Walzer, entre outros -, os padrões de Justiça devem ser fundamentados nas formas de vida e nas tradições de cada sociedade particular, sendo, consequentemente, variável de contexto para contexto. Inspirado na discussão sobre ética de Aristóteles, o comunitarismo defende uma concepção de justiça enraizada nos valores cultivados coletivamente. Usualmente, a proposta comunitarista consiste num modelo de organização de sociedade sustentada a partir de valores particulares de sua tradição - o conjunto de princípios que aquela comunidade define como sendo o bom definirá o que ela considera como justo ou injusto -, e os direitos individuais carecem de um equilíbrio baseado em responsabilidade social. (Cf. TAYLOR, 1997; SILVA, 2001).

19 O termo "corporativo" é usado aqui no sentido de unidade de um corpo, cujas partes pensam como iguais (ou pensam como a maioria hegemônica).

20 Trouillot propõe que, para a identificação, análise e observação desses "efeitos de Estado" seria necessária a subtração da própria ideia de Estado como um bloco coeso e homogêneo, uma vez que há diferentes focos de onde emanam e são postos em prática os efeitos de Estado. Nesses parâmetros, o Estado aparece como algo aberto, dinâmico, "não teria seus limites traçados e estabelecidos no escopo da estrutura organizacional das entidades estatais e poderia passar a ser compreendido como uma série de praticas, processos e
}

Caderno Eletrônico de Ciências Sociais, Vitória, v. 8, n. 1, pp. 60-90, 2020. 
serviços têm o seu caráter estruturante de relações sociais entre as igrejas e os fiéis. Ao atuarem como "mediadores de demandas locais e interesses" relacionados às suas redes políticas (BEZERRA, 1999, p. 256), os megatemplos cumprem a expectativa de uma solidariedade corporativa, ao se mostrarem enquanto agentes "provedores" das demandas de conforto da matéria e do espírito.

\section{Megatemplos evangélicos na experiência urbana - Rio de Janeiro e Curitiba}

O case etnográfico para o exame das características particulares do megatemplo evangélico brasileiro considera como universo amostral as megaigrejas Templo da Glória do Novo Israel (também chamada de Templo Maior), da Igreja Universal do Reino de Deus, no Rio de Janeiro, e a Primeira Igreja Batista do Batel, em Curitiba (PIB Curitiba). Selecionei esses santuários levando em conta seus atributos particulares na história do surgimento dos megatemplos no Brasil. Ambas as igrejas estão entre os primeiros projetos ${ }^{21}$ arquitetônicos para megatemplos evangélicos nos anos 1990, possuindo, portanto, características que enriquecem a perspectiva analítica do tema. $O$ Templo Maior/RJ e a PIB Curitiba estão em metrópoles diferentes e com contrastes específicos, são provenientes de duas correntes evangélicas diferentes - pentecostal e histórica. Além disso, ambas possuem atuação em classes sociais diversas e adotam linguagens estéticas e discursivas únicas, apresentando afinidades entre si.

\section{Templo da Glória do Novo Israel - IURD Del Castilho/RJ}

Ao descrever um breve histórico da implantação, atuação e relevância do megatemplo IURD no Rio de Janeiro considero importante metabolizar o contexto em que ele se insere, que é o da zona norte suburbana, para que então seja possível compreender o porquê de esse megatemplo ter causado amplas transformações nesse espaço.

efeitos presentes em uma diversidade considerável" de formas e contextos na vida cotidiana (SANTANNA-PORTO, 2017, p. 180).

${ }_{21}$ Com base nos estudos de Thumma e Travis (2007), Wilford (2012) e Bratton (2016) sobre a perspectiva temporal dos megatemplos na América Latina, corroborei que o início desse fenômeno no Brasil ocorreu nos anos 1990 através de fontes bibliográficas, acervos jornalísticos da Biblioteca Nacional e em consulta às secretarias municipais de urbanismo nas cidades pesquisadas. A IURD Del Castilho iniciou o projeto do Templo Maior em 26/08/1996 (apud SME/4aGLF região/Ramos, 2018[1996]) e a PIB Curitiba protocolou o projeto de abertura à construção do megatemplo em 28/03/1990 (apud Secretaria Municipal de Desenvolvimento Urbano de Curitiba, 2018[1990]). Os arquitetos autores de ambos os projetos também colaboraram para o levantamento dessas informações, durante entrevistas realizadas entre janeiro e fevereiro de 2019.

Caderno Eletrônico de Ciências Sociais, Vitória, v. 8, n. 1, pp. 60-90, 2020. 
O santuário se encontra no bairro de Del Castilho e faz limite com os bairros de Higienópolis, Maria da Graça, Cachambi e Inhaúma. O bairro possui extensão territorial de 144 hectares; é composto por edifícios e casas antigas e tem valor irrisório de áreas verdes $(0,41 \mathrm{ha})$. O Índice de Desenvolvimento Social da cidade do Rio de Janeiro (2010) aponta que Del Castilho contém uma população em cerca de 15.610 pessoas - faixa de classificação menor que 20.000 habitantes - por isso o bairro é considerado como "zona de ocupação incentivada" (IPP, 2017). A população, que possui renda média de até 5 salários mínimos, está inserida entre as menores classificações de renda da cidade (ARMAZÉM DE DADOS/IPP, 2018).

A relação da IURD com Del Castilho e o subúrbio do Rio de Janeiro data da década de 1970, período de sua fundação, quando a Igreja Universal do Reino de Deus adotava o estilo "franquia", alugando galpões, cinemas, teatros ou espaços ociosos comumente utilizados para outras finalidades. Segundo Edlaine Gomes (2011), em meados da década de 90 a associação tensa e conflituosa estabelecida pela igreja com diferentes interlocutores notadamente após o episódio do "chute à Santa"22 -, assim como a questão da autenticidade foram identificados como questões relevantes para mudar a compreensão da relação desta igreja com seus interlocutores, para desmistificar o caráter de "igreja-seita".

Nesse momento a IURD passou a buscar a "concretização material das ideias de permanência, continuidade, vínculo com uma memória e história" (GOMES, 2011, p. 114). Tais noções rompem com a imagem de fluidez e descompromisso com o tempo e espaço, sugerido pelo estilo franquia. A noção de autenticidade da IURD proporia, assim, uma originalidade que the fosse peculiar, especialmente o diálogo com a cidade - no sentido da intervenção na paisagem urbana com a instalação de novos monumentos e grandes concentrações em locais públicos.

A construção de uma sede com aspecto de um lugar de memória e ícone urbano atuou como o principal suporte da materialização do projeto de igreja da IURD. Inaugurado em 25 de abril de 1999, o Templo da Glória do Novo Israel foi concebido e edificado para expressar uma identidade distinta e fortalecida. Projetado pelo casal de arquitetos Norma Taulois e Cláudio Taulois ${ }^{23}$, o

22 Episódio televisivo ocorrido em 1995, quando Sérgio Von Helde (ex-bispo da IURD)
proferiu insultos verbais e físicos contra uma imagem de Nossa Senhora Aparecida durante
o programa matutino "O Despertar da Fé", transmitido pela Rede Record. Na ocasião, Von
Helde protestava contra o caráter do feriado nacional de 12 de outubro (dia de Aparecida,
considerada pelos católicos como padroeira do Brasil). O acontecimento provocou forte
repercussão na mídia e em grande parte da sociedade brasileira.
23 Fundadores da Taulois \& Taulois Arquitetos, empresa de serviços de consultoria e
planejamento nas áreas de arquitetura, paisagismo e urbanismo. Norma e Claudio podem
ser considerados também como mentores do primeiro projeto ao Jardim Bíblico (hoje

Caderno Eletrônico de Ciências Sociais, Vitória, v. 8, n. 1, pp. 60-90, 2020. 
megatemplo tem 72 mil metros quadrados de área construída, sendo que apenas o santuário, onde são realizados os cultos, mede 45 mil metros quadrados (GLF/SMU-RJ, 2018). O megatemplo tem quatro pavimentos, mas com dimensões correspondentes a um imóvel de dez andares (Figuras 6 a 8 ).

Figuras 6 e 7: Vista aérea do Templo da Glória do Novo Israel; hall de entrada do Centro Cultural Jerusalém.
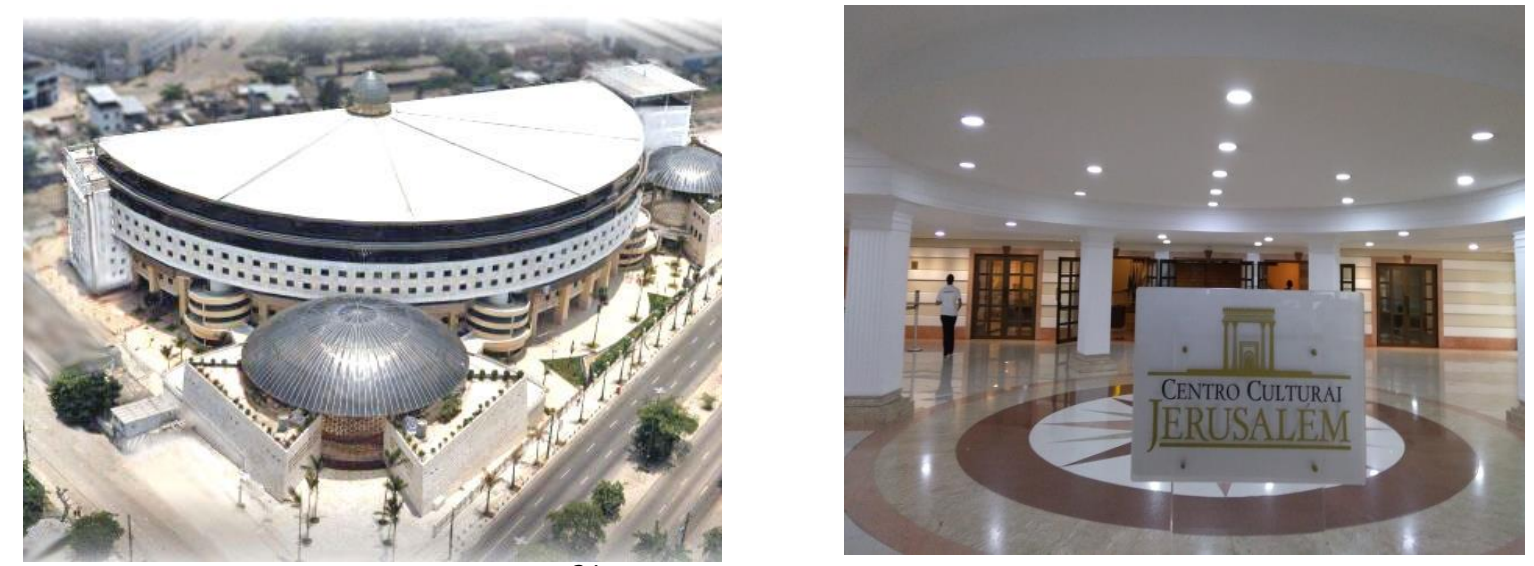

Fonte: Universal.org ${ }^{24}$ (Reprodução); Levantamento de campo (2018).

Figura 8: Paisagem do Templo da Glória do Novo Israel.

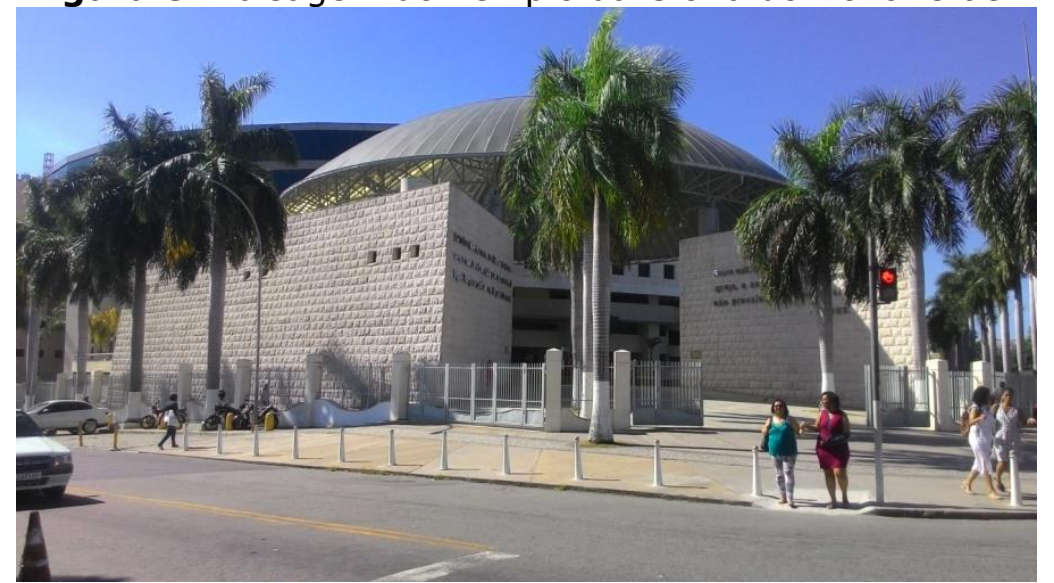

Fonte: Levantamento de Campo/Rita Gonçalo (2019).

O bairro de Del Castilho detém boa oferta de transportes públicos (Mapa 1). Em um raio de $600 \mathrm{~m}$ a partir do local do templo tem-se uma estação de metrô com integração para as regiões da Barra da Tijuca e Jacarepaguá, Ilha do Fundão e Baixada Fluminense; uma estação de trem que interliga Del Castilho

presente no Templo de Salomão-Brás-SP), que seria inicialmente criado no anexo ao megatemplo IURD Del Castilho. O projeto inaugural proposto por Norma e Claudio constava a criação de um parque temático com elementos bíblicos que pudessem contar a história de Israel para a população do subúrbio carioca. Era interesse dos arquitetos que o templo fosse mais do que um equipamento religioso, e assim deixasse um legado cultural para os cariocas. Fonte: Levantamento de campo, entrevista com Norma Taulois, janeiro de 2019. 24 Disponível em: https://sites.universal.org/universal40anos/artigo/32-a-primeira-sedemundial-da-universal. Acesso em: 14 ago. 2018.

Caderno Eletrônico de Ciências Sociais, Vitória, v. 8, n. 1, pp. 60-90, 2020. 
às zonas Centro, Oeste e Baixada Fluminense da região metropolitana do Rio; pontos de táxi; diversas linhas de ônibus, e dois amplos estacionamentos - um que integra o conjunto do Templo Maior e Centro Cultural Jerusalém ${ }^{25}$, da IURD, e outro que pertence ao Shopping Nova América. No raio entre 50 e $600 \mathrm{~m}$ a partir do templo há 10 paradas de ônibus. A oferta de mobilidade urbana é fator preponderante para a estruturação de um megatemplo, sendo importante considerar a criação ou melhoria de uma gama de infraestrutura de mobilidade e serviços, posto que a forma como os fiéis se locomovem para experimentar o templo também deve ser socialmente organizada.

Mapa 1: Serviços de mobilidade urbana em Del Castilho no entorno do megatemplo.

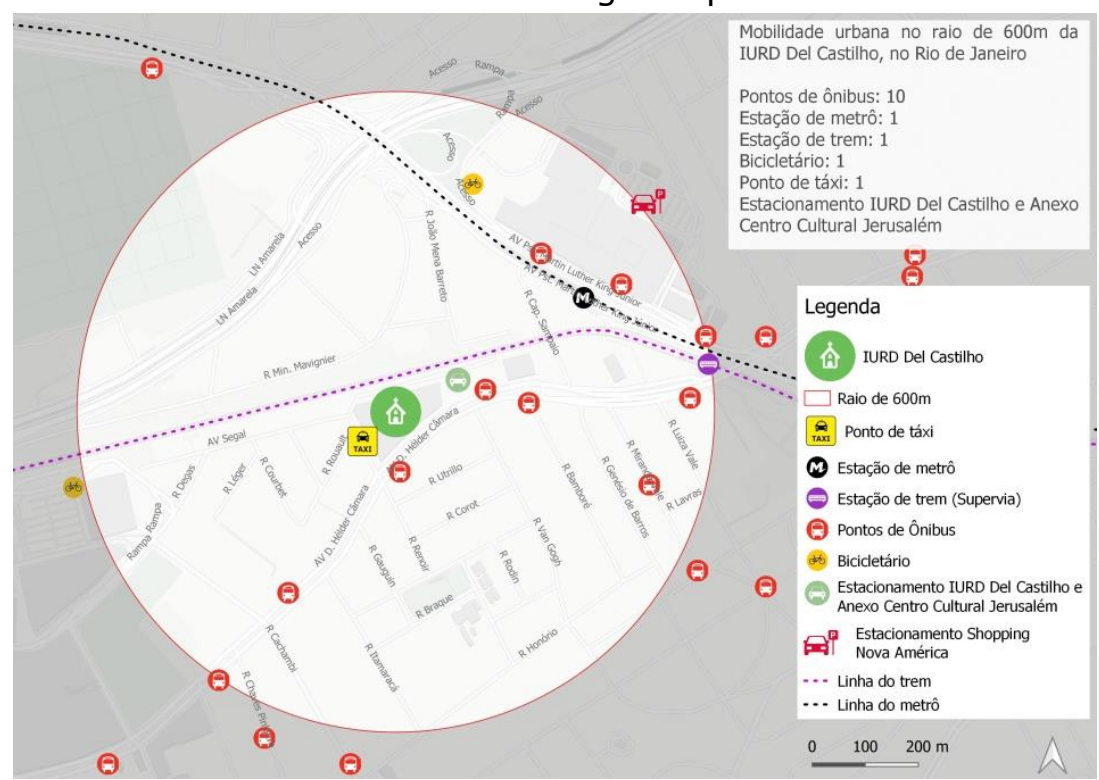

Elaboração: Victor Ricardini \& Rita Gonçalo (2020).

Fonte: ArcGIS Pro (2020); SMTR/Prefeitura do Rio (2020).

Apesar da boa oferta de transportes, Del Castilho não possui equipamentos municipais de esporte e cultura (IPP, 2018). A falta de equipamentos culturais fez com que o megatemplo da IURD assumisse um lugar de importância na região, tornando-se uma das principais referências como ponto de encontro religioso e de lazer, sendo ainda citado por mídias importantes no campo do turismo cultural - como os sites TripAdvisor, Rolé Carioca e Cadastro Nacional de Museus, do Iphan.

${ }^{25}$ O Centro Cultural Jerusalém - CCJ abriga a exposição permanente da segunda maquete de Jerusalém da época dos tempos de Jesus construída no mundo. Além da maquete, os visitantes também encontram outras exposições, eventos e atrações como coffeshop e loja de souvenirs e artigos judaicos. Outras informações sobre o CCJ estão descritas no artigo Megatemplos Evangélicos: Linguagens híbridas e estéticas de consumo no espaço sagrado (GONÇALO, 2019).

Caderno Eletrônico de Ciências Sociais, Vitória, v. 8, n. 1, pp. 60-90, 2020. 
Ao pensar o conjunto das necessidades urbanas que englobam um conjunto de esferas às camadas populares e médias do Rio de Janeiro, o Templo da Glória do Novo Israel estabelece um plano de prioridades para espacializar seu processo de intervenção na cidade e nos indivíduos urbanos. A síntese das características que compõem o Templo da Glória do Novo Israel é descrita no Quadro 1:

Quadro 1: Templo da Glória do Novo Israel - síntese.

\begin{tabular}{|c|c|c|}
\hline \multirow{4}{*}{ Dados gerais } & Ano de construção & 1996 \\
\cline { 2 - 3 } & Inauguração & 1999 \\
\cline { 2 - 3 } & $\begin{array}{c}\text { Arquiteto(s) autor(es) do } \\
\text { projeto }\end{array}$ & $\begin{array}{c}\text { Norma Taulois e Cláudio Azevedo } \\
\text { Taulois }\end{array}$ \\
\cline { 2 - 3 } & Área/ocupação total $\left(\mathrm{m}^{2}\right)$ & 72.000 \\
\cline { 2 - 3 } & Bairro/zona & $\begin{array}{c}\text { Del Castilho (subúrbio do RJ, } \\
\text { classe média-baixa) }\end{array}$ \\
\cline { 2 - 3 } & Líder principal & Bispo Jadson Santos \\
\cline { 2 - 3 } & Ministérios e projetos & 30 (em atividade) \\
\hline
\end{tabular}

Fonte: Levantamentos de campo (2018-2019).

O perímetro de entorno do bairro e a IURD marcam a fronteira entre a bricolagem miúda e pálida de Del Castilho e a vastidão estética do Templo Maior (FREIRE-MEDEIROS \& SILVA, 2019). São recursos que ajudam a focar o olho do frequentador para o templo, isolando quaisquer estímulos exteriores.

A arquitetura do megatemplo e seu anexo, o Centro Cultural Jerusalém, contribuem com a capacidade de reforçar simbolicamente a posição ocupada pela IURD como "detentora do vocabulário e das materialidades necessárias para fazer a ponte entre as culturas evangélica e judaica" (FREIRE-MEDEIROS \& SILVA, 2019, p. 99). A concepção de sua estrutura nos permite pensar que ali se encontraria um dos centros do "mundo iurdiano", seu lugar de memória. Desta maneira, o princípio que perpassa a sua construção é o de estabelecer uma distinção entre a IURD e os demais segmentos religiosos. Este é um componente significativo para pensarmos de que maneira esse megatemplo indica a forma com a qual a IURD elabora sua identidade, em referência à nação de Israel, caracterizada pelo conceito de "terra prometida" e pela noção de crescimento e expansão. Percebe-se que o Templo da Glória do Novo Israel foi elaborado de acordo com essa mesma lógica - a de ser grandiosa e monumental em meios aos "vazios urbanos e institucionais", expressando materialmente o que a IURD pretende ser.

\section{Primeira Igreja Batista de Curitiba - Batel/CTBA}

A Primeira Igreja Batista de Curitiba (PIB Curitiba) foi fundada ano de 1914, mas o planejamento para a construção do novo templo começou no ano de 1977, quando a igreja adquiriu o atual terreno vendido pela família

Caderno Eletrônico de Ciências Sociais, Vitória, v. 8, n. 1, pp. 60-90, 2020. 
Matarazzo ${ }^{26}$. O terreno do templo está localizado no perímetro entre as ruas Bento Viana, Visconde de Guarapuava e Avenida Batel, uma das áreas mais nobres da Grande Curitiba. Antes do novo templo ser construído, foi levantado inicialmente um ginásio onde funcionavam as atividades esportivas, culturais e sociais da igreja, e onde se celebravam também os cultos dominicais.

Os gestores da Primeira Igreja Batista tinham um sonho guardado há tempos: o de se tornarem a principal e mais relevante igreja evangélica na cidade de Curitiba. Àquela época, década de 70 , não havia práticas que pudessem estimular o aumento da capitalização dos recursos da igreja e, por isso, a obra demorou décadas até chegar ao estágio final. Embora fosse uma igreja tradicional, a PIB Curitiba ganhou fama de "mal vista" na cidade em função de a obra nunca ficar pronta.

Para reverter esse quadro, em 1990 foi instalada uma Comissão de Construção presidida pelo então deputado federal André Zacharow, que era membro da PIB. André Zacharow era um homem de muitas relações políticas na prefeitura e no campo do planejamento urbano. Foi através dele que a igreja chegou até o famoso arquiteto Luiz Forte Netto, responsável pelo projeto do atual megatemplo, que, na época, atuava tanto em seu escritório particular quanto na Secretaria de Desenvolvimento Urbano do estado do Paraná, na área de financiamento de projetos.

O briefing do edital de chamada ao projeto expunha claramente que as razões da igreja em construir o megatemplo eram expandir sua atuação de responsabilidade social - principalmente nas áreas de educação, música e assistência social - além de conseguir mais adeptos, transmitir os princípios da religião e atuar socialmente no que diz respeito ao desenvolvimento da cidade. Forte Netto afirma que os batistas da PIB queriam transmitir qual a importância da religião no mundo e na cidade de Curitiba. A partir desse interesse de expansão eles precisavam de um templo grande. O projeto vencedor propunha uma igreja com três blocos integrados: um em que funcionaria o santuário principal, com capacidade para 5 a 7 mil pessoas em reuniões rotativas, e outros dois edifícios que reuniriam as atividades administrativas, educacionais e de assistência social.

A ideia de integrar ao projeto a composição de vitrais na fachada principal, que fica de frente para a Avenida Batel, surgiu do desejo dos membros da PIB Curitiba para que o santuário tivesse um componente estético que fosse a marca da igreja na cidade. A composição dos vitrais tinha por objetivo procurar conduzir o homem para uma situação "mágica" de vida infinita. Os vitrais buscaram, portanto, contar a história da religião cristã no

\footnotetext{
${ }^{26}$ Levantamento de campo, 2019. Entrevistas com Nilson Vital Oliveira (PIB Curitiba) e Luiz Forte Netto (arquiteto), fevereiro de 2019.
}

Caderno Eletrônico de Ciências Sociais, Vitória, v. 8, n. 1, pp. 60-90, 2020. 
mundo, para compelir o espectador a realmente acreditar que Deus existe e que é o condutor de toda a humanidade.

Figura 9: Megatemplo PIB Curitiba - vista do santuário e blocos anexos.

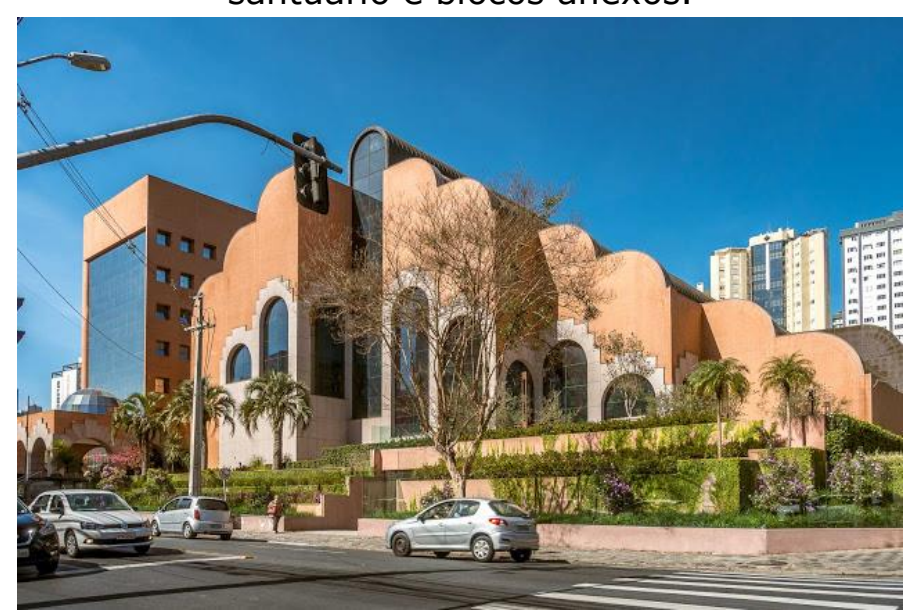

Foto: TripAdvisor (2019) ${ }^{27}$.

Figura 10: Interior da igreja e vitrais - PIB

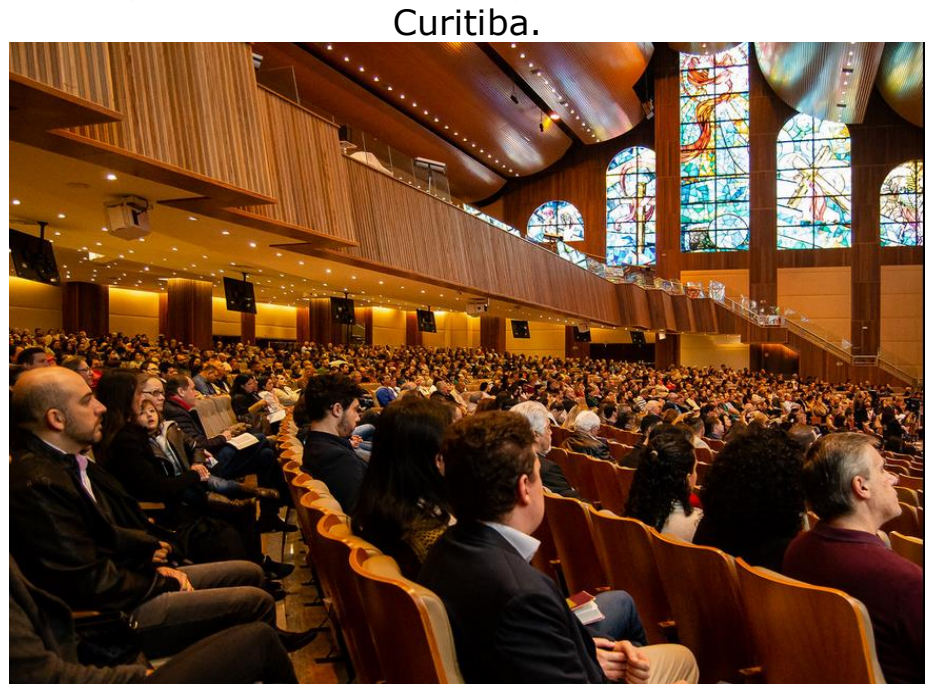

Fonte: Levantamento de campo/Rita Gonçalo (2019).

A questão dos vitrais estaria mais adequada à identidade da igreja em termos econômicos e simbólicos. Segundo Paschoal Piragine, pastor presidente da PIB Curitiba:

[os vitrais] tem muito a ver com o estilo da igreja, o local que a igreja está, e o povo que frequenta a igreja. O lugar é nobre, e embora tenhamos pessoas de todas as classes, o público que frequenta em geral é de classe média-alta. Nossa igreja está num

27 Disponível em: https://www.tripadvisor.com.br/Attraction_Review-g303441-d7930735Reviews-Primeira_Igreja_Batista_de_Curitiba-Curitiba_State_of_Parana.html. Acesso em: 12 mai. 2020. 
lugar nobre que é um point da cidade, e sempre houve no coração da igreja que esse templo fosse um marco na cidade de Curitiba de alguma maneira. Todo esse nosso trabalho também tem a ver com essa ideia. Você vai perceber que o pessoal do Sul é muito detalhista; eles gostam das coisas tudo arrumadinho, bonitinho, da melhor maneira possível, então acho que isso faz parte de uma identidade cultural da região também. [Pr. Paschoal Piragine, Entrevista de campo, maio de 2018].

Em relação à mobilidade urbana, muitos membros e visitantes da PIB possuem veículo, sendo assim, o que predomina é a ida de carro para a igreja. O estacionamento da PIB atualmente já não comporta a quantidade de carros que se avoluma nos cultos - especialmente os de fins de semana. Como alternativa, os gestores do megatemplos fecharam parceria com todos os estacionamentos privados do raio no Batel. Os que não conseguem estacionar na igreja podem guardar seus veículos nesses locais a um preço com dedução no valor normal da tarifa ${ }^{28}$.

Mapa 2: Circuito de mobilidade urbana no entorno do templo PIB Curitiba.

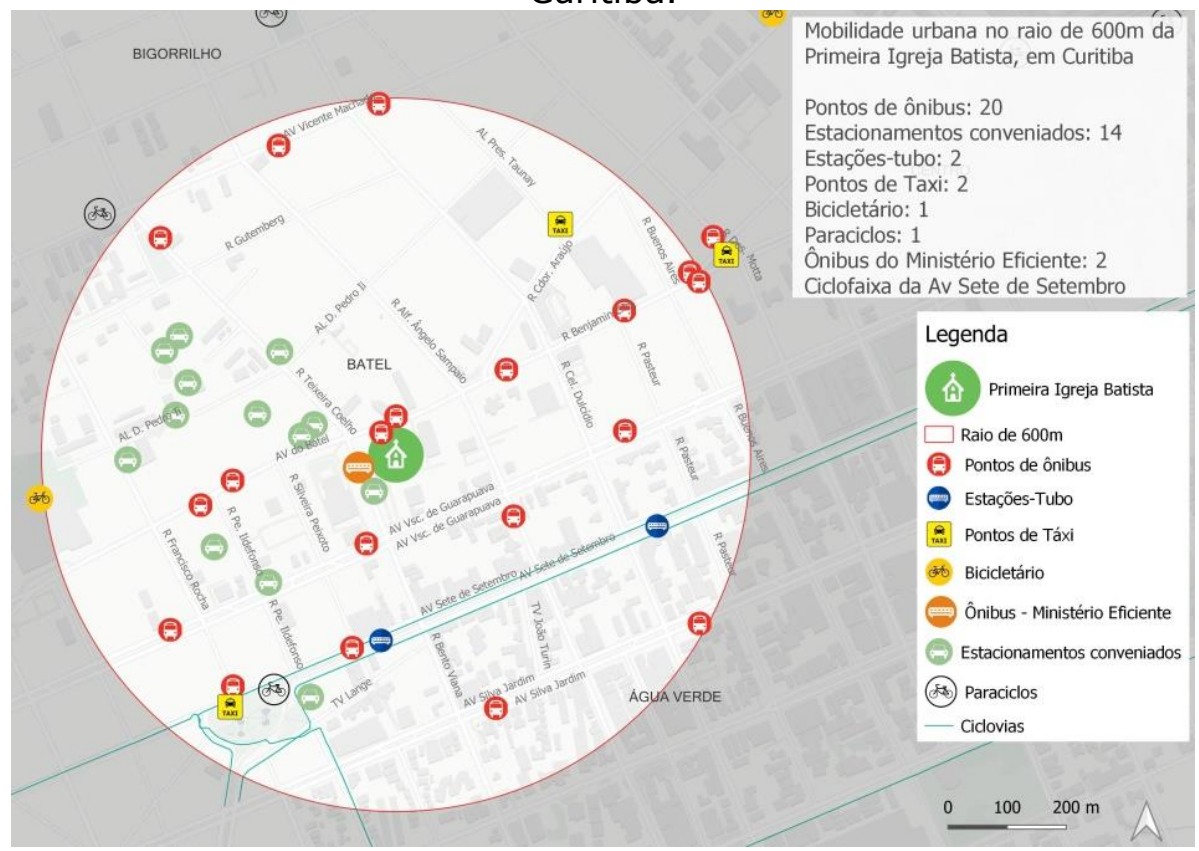

Elaboração: Victor Ricardini \& Rita Gonçalo (2020).

Fonte: ArcGIS Pro (2020); IPPUC-MetroGEO (2020).

Em um raio de $600 \mathrm{~m}$ a partir da igreja Batista há 20 paradas de ônibus, o que colabora para a movimentação de fiéis de camadas mais populares oriundos de outros bairros. Outro elemento que favorece a mobilidade dos que

${ }^{28}$ Levantamento de campo, 2019. Entrevistas com Nilson Vital Oliveira (PIB Curitiba), fevereiro de 2019.

Caderno Eletrônico de Ciências Sociais, Vitória, v. 8, n. 1, pp. 60-90, 2020. 
não possuem carro são as estações-tubo ${ }^{29}$ (Estações Coronel Dulcídio e Bento Viana 1) dos ônibus articulados da rede integrada Curitiba. As proximidades da igreja possuem, ainda, paraciclo e bicicletário para os usuários das ciclovias. Os pontos de táxi ficam um pouco mais distantes.

A PIB Curitiba possui dois ônibus de viagem para a mobilidade de frequentadores e membros portadores de alguma deficiência. Esses veículos atendem especificamente ao Ministério Eficiente e às reuniões promovidas por este - destinados ao atendimento e acolhimento de cadeirantes, deficientes visuais, surdos, intelectuais.

Para além das características socioespaciais particulares, o Batel tem figurado no imaginário local como o sendo o "bairro da igreja Batista". Isto porque a PIB, depois da inauguração em 2014, tornou-se de fato um ícone religioso na capital curitibana. O carro-chefe para essa ressonância na comunidade não é caracterizado apenas pela beleza dos vitrais, mas especialmente pelas celebrações musicais que a igreja realiza. O Nataleluia, evento de Natal que a PIB Curitiba promove há 21 anos, é o principal espetáculo natalino que acontece na cidade. Migrantes de todas as partes de Curitiba e região Sul vão ao Batel prestigiar esse evento, que tem patrocínio oficial da Prefeitura e de empresas privadas, como o banco Bradesco. O evento Nataleuia foi o responsável por alçar a PIB à categoria de ponto turístico da capital curitibana, tanto que a igreja já protagoniza espaços nos sites especializados de roteiro turístico, como TripAdvisor, The Cities e Curitiba City.

O Nataleluia integra o calendário oficial de programações natalinas da cidade. Ele é realizado durante quatro dias seguidos e recebe o suporte operacional da Polícia Militar, BPTran (Batalhão de Trânsito) e Corpo de Bombeiros, devido ao intenso trânsito de pessoas e veículos que ocorre em decorrência da atração.

Emissoras de mídia também fazem a cobertura do evento, tais como SBT, Band, Rede Brasil de Comunicação, Rede Super e o portal G1 da Globo. O Nataleluia conta com duas áreas especializadas para sua realização: Direção Artística e Direção Executiva. A criação do espetáculo começa um ano antes de sua execução, que sempre acontece na semana de véspera do Natal. Na fase de planejamento, a comissão do evento decide se o musical será autoral ou se eles comprarão direitos de produção de musicais estrangeiros. A parte operacional

29 Pontos de parada específicos dos ônibus articulados que interligam toda a região da Grande Curitiba, considerando 29 municípios do estado do Paraná. As estações-tubo são parte de um conjunto de equipamentos urbanos que buscavam criar uma unidade visual marcante para a capital paranaense. O formato oval ilustra a estética icônica e a funcionalidade trazida pelos tubos. Implantadas na década de 1990, a Grande Curitiba conta com 329 estações-tubo, onde o viajante pode se transportar de uma ponta a outra da cidade com uma passagem modal. Cf. URBS Curitiba (2019).

Caderno Eletrônico de Ciências Sociais, Vitória, v. 8, n. 1, pp. 60-90, 2020. 
(montagem, transportes etc.) é feita entre 3 a 4 meses antes. A cada ano o evento conta com um cenário diferente, tema e figurino distintos. Vez por outra fazem releituras de cantatas antigas, mas sempre com uma roupagem nova.

A síntese das características que compõem o megatemplo Primeira Igreja Batista de Curitiba é descrita no Quadro 2:

Quadro 2: Primeira Igreja Batista em Curitiba - síntese.

\begin{tabular}{|c|c|c|}
\hline \multirow{4}{*}{ Dados gerais } & Ano de construção & 1990 \\
\cline { 2 - 3 } & Inauguração & 2014 \\
\cline { 2 - 3 } & $\begin{array}{c}\text { Arquiteto autor do } \\
\text { projeto }\end{array}$ & Luiz Forte Netto \\
\cline { 2 - 3 } & $\begin{array}{c}\text { Área/ocupação total } \\
\text { (m2) }\end{array}$ & $\begin{array}{c}\text { Batel (na região central de Curitiba, } \\
\text { classe média-alta) }\end{array}$ \\
\cline { 2 - 3 } & Bairro/zona & Pastor Paschoal Piragine \\
\cline { 2 - 3 } & Ministérios & $\begin{array}{c}40 \text { (com diferentes ramificações, que } \\
\text { totalizam mais de 100 projetos em } \\
\text { atividade) }\end{array}$ \\
\hline
\end{tabular}

Fonte: Levantamento de campo (2018-2019).

Devido ao reconhecimento da igreja como autoridade religiosa na capital curitibana, a PIB Curitiba consegue construir relações de rede bastante profícuas com a Prefeitura Municipal. Lideranças da PIB Curitiba são convidadas pelo prefeito, os empresários e demais personalidades importantes no município quando há qualquer decisão a ser tomada que envolva o bairro do Batel ou a participação da igreja na esfera pública. Como Paschoal Piragine, pastor presidente da PIB, que atua como espécie de "conselheiro espiritual" para os gestores públicos no município.

Enquanto identidade religiosa socialmente valorizada, a PIB Curitiba legitima o acesso ao espaço público em busca de apoio para a realização de seus projetos sociais e a expansão de direitos. Cabe assinalar que os dirigentes da PIB fazem do pertencimento evangélico um instrumento importante de atuação política. Nas etnografias de campo realizadas foi possível perceber o quanto eles se orgulham do acesso direto que possuem com os governantes, bem como o tratamento diferencial que usufruem da parte destes.

\section{Considerações finais}

A criação de megatemplos evangélicos é um fenômeno histórico que, em linhas gerais, acompanha o processo de urbanização de grandes cidades. Configura-se como um elemento estratégico das igrejas com potencial econômico a fim de expandir seus interesses em um dado território. Demonstrei que no século XX diferentes denominações evangélicas nos Estados Unidos

Caderno Eletrônico de Ciências Sociais, Vitória, v. 8, n. 1, pp. 60-90, 2020. 
investiram na implantação de megachurches junto aos grandes centros econômicos. As lideranças evangélicas brasileiras acompanhavam essa tendência e, na década de 1990, o fenômeno começou a ganhar contornos no Brasil, a partir da criação dos megatemplos IURD Del Castilho e Primeira Igreja Batista de Curitiba, referenciais de análise para esta pesquisa.

Para Halbwachs (1990, p.157), "não há grupo religioso sem expressão no território, sem qualquer vínculo com um local que fixe suas lembranças comuns". Ao fio condutor da hipótese inicial deste texto, podemos concluir que o megatemplo evangélico surge no urbano como manifestação das estratégias de crescimento, consolidação e permanência de denominações evangélicas reconhecidas e de poder político relevante, daí o abandono ao antigo recurso por somente ocupar espaços já edificados. A "estratégia" aqui pode ser entendida como iniciativa de diferenciação e competição.

A capacidade de organizar um espaço "advém de todo um complexo de relações mobilizadas por diversos agentes sociais" (HARVEY, 1996, p. 52). A formação de alianças e coalizões políticas são a base desse perfil de estratégia urbana. No caso do megatemplo, essas relações são protagonizadas pelos pastores, gestores de igrejas e lideranças políticas que, juntos, buscam legitimar a paisagem evangélica no urbano. O que está em jogo são os marcos especiais de distinção, que dependem de valores como autenticidade, singularidade e qualidades específicas não replicáveis nas igrejas menores. Trata-se de visibilizar os megatemplos por meio de um estilo próprio de arquitetura e mercado de serviços, concebidos para manifestar intenção de permanência, lugares para serem referenciados e lembrados.

Há ainda, entre a miríade de motivações estratégicas que norteiam os pastores para criar megatemplos e arregimentar pessoas para Cristo, o intuito em ocupar um lugar de legitimidade que o Estado fez desaparecer com sua ausência entre as camadas urbanas. Neste sentido, coube aos megatemplos modernos atualizarem seu ambiente construído para melhor cumprir seus serviços. Novos espaços e relações espaciais são produzidos para dar vazão a outros imperativos. A lógica que fomenta esse empreendimento ambicioso é a da estratégia de urbanidade, para a qual o megatemplo e seus serviços representam uma das "saídas" às problemáticas urbanas, aos contextos de ordem/desordem específicos das cidades.

O megatemplo evangélico contemporâneo não apenas cumpre a função aglutinadora de fiéis: ele, além disso, inova e dinamiza sua oferta de serviços para atender a um público cada vez mais frequente e plural. Os múltiplos serviços para os fiéis com a pretensão de "diversidade" expressa como a religião evangélica assume novos contornos nos tempos atuais, em que procura responder às aspirações e aos desejos que emergem na sociedade, oferecendo

Caderno Eletrônico de Ciências Sociais, Vitória, v. 8, n. 1, pp. 60-90, 2020. 
um mercado de consumo em serviços socioespirituais como fonte de satisfação e experiência.

\section{Referências bibliográficas}

ALVES, J. E. D. et al. Distribuição espacial da transição religiosa no Brasil. Tempo Social - Revista de Sociologia da USP, v. 29, n. 2, pp. 215-242, 2017.

ARCGIS Pro - ESRI (Software). 2018. Disponível em: https://www.esri.com/enus/arcgis/products/arcgis-pro/overview. Acesso em: 03 out. 2018.

ARMAZÉM DE DADOS - IPP/RJ. 2018. Informações e estatísticas sobre o Rio. Disponível em: http://www.armazemdedados.rio.rj.gov.br/. Acesso em: 03.10.2018.

BEZERRA, M. 1999. Em nome das "bases": política, favor e dependência pessoal. Rio de Janeiro: Relume-Dumará/NuAP.

BOURDIEU, P. 2017. Questões de sociologia. Rio de Janeiro: Marco Zero, 1983.

BRATTON, S. P. 2016. Megachurches and the Iconography of Environment. Waco, Texas: Baylor University Press.

CADASTRO NACIONAL DE MUSEUS - IPHAN. 2020. Centro Cultural Jerusalém. Disponível em: https://bit.ly/3cvQkaI. Acesso em: 11.05.2020.

CAMPBELL, C. 2002. A ética romântica e o espírito do consumismo moderno. Rio de Janeiro: Rocco.

CENTRO CULTURAL JERUSALÉM. 2016. Sobre nós. Disponível em: http://centroculturaljerusalem.com.br/about-2/. Acesso em: 12 mai. 2020.

DARDOT, Pierre; LAVAL, Christian. 2016. A nova razão do mundo: ensaio sobre a sociedade neoliberal. São Paulo: Editora Boitempo.

FERREIRA, Á.; RUA, J.; MATTOS, R. C. 2014. Desafios da metropolização do espaço. Rio de Janeiro: Consequência.

FREIRE-MEDEIROS, B.; SILVA, N. P. 2019. Um passeio além do temp(I)o: Mobilidades, mídia e memória no Jardim Bíblico do Templo de Salomão. In: FARIAS, E. F.; NERY, S. (Orgs.). Durações e redes de fluxos no cenário cultural contemporâneo. Paco e Littera, pp. 79-102.

GOMES, E. C. 2011. A era das catedrais: a autenticidade em exibição. Rio de Janeiro: Garamond.

GONÇALO, R. 2019. Megatemplos Evangélicos: Linguagens híbridas e estéticas de consumo no espaço sagrado. Mosaico FGV, v. 10, n. 16, pp. 52-72.

Caderno Eletrônico de Ciências Sociais, Vitória, v. 8, n. 1, pp. 60-90, 2020. 
HAESBERT, R. 2007. Território e multiterritorialidade: um debate. GEOgraphia, Ano IX, n. 17, pp. 19-46.

HALBWACHS, M. 1990. A Memória coletiva. São Paulo, Vértice/Revista dos Tribunais.

HARVEY, D. 2005. A produção capitalista do espaço. São Paulo: Annablume.

HARVEY, D. 1996. Do gerenciamento ao empresariamento: a transformação da administração urbana no capitalismo tardio. Espaço e Debates, n. 39, pp. 48-65.

INSTITUTO PEREIRA PASSOS - IPP. 2017. Índice de Desenvolvimento Social IDS: Comparando as realidades microurbanas da cidade do Rio de Janeiro. Disponível em: https://bit.ly/2yWeMmZ. Acesso em: 03 out. 2018.

INSTITUTO DE PESQUISA E PLANEJAMENTO URBANO DE CURITIBA - IPPUC. 2020. Sistema Metropolitano de Informações Georreferenciadas (METROGEO). Disponível em: http://www.metrogeo.org.br/. Acesso em: 05.05.2020.

LEFEBVRE, H. 1999. A revolução urbana. Belo Horizonte: Editora UFMG.

MAFRA, C. 2013. O que os homens e as mulheres podem fazer com números que fazem coisas. In: TEIXEIRA, F.; MENEZES, R. (Orgs.). Religiões em movimento: o censo de 2010. Petrópolis: Vozes, pp. 173-192.

MAFRA, C.; ALMEIDA, R. 2009. Religiões e Cidades - Rio de Janeiro e São Paulo. São Paulo. Terceiro Nome.

MARANHÃO FILHO, E. M. 2010. A grande onda vai te pegar: mercado, mídia e espetáculo da fé na Bola de Neve Church. Dissertação de Mestrado. Universidade do Estado de Santa Catarina (UDESC), Florianópolis.

NERI, M. 2019. As classes médias brasileiras. Rio de Janeiro: FGV Social/ Centro de Políticas Sociais.

OLIVEIRA, R. H. 2013. A igreja local em diversos locais - "multi-site church": alternativa inovadora para o crescimento de igrejas locais. Theos - Revista de Reflexão Teológica da Faculdade Teológica Batista de Campinas. Edição 9, v. 8, n. 2, pp. 1-20.

PECHMAN, R. 2002. Cidades estreitamente vigiadas: o detetive e o urbanista. Rio de Janeiro: Casa da Palavra.

REIS, E. P. 1998. Sobre a cidadania. In: REIS, E. P. (Org.). Processos e escolhas. Estudos de sociologia política. Rio de Janeiro: Contra Capa. 
RUA, J. 2014. Governança democrática metropolitana: como construir a "cidade dos cidadãos"? In: FERREIRA, Á.; RUA, J.; MATTOS, R. C. Desafios da metropolização do espaço. Rio de Janeiro: Consequência.

RUIZ, R. M. 2005. Estruturas urbanas comparadas: Estados Unidos e Brasil. Estudos Econômicos, São Paulo, v. 35, n.4, pp. 715-737.

SANTANNA-PORTO, J. R. 2017. Notas sobre os efeitos e a ideia de Estado. Revista de Discentes de Ciência Política da UFSCAR, v. 5, n. 2, pp. 171-194.

SECRETARIA MUNICIPAL DE DESENVOLVIMENTO URBANO DE CURITIBA. 1990. Processo no 18.833/1990.

SECRETARIA MUNICIPAL DE TRANSPORTES - SMTR/ Prefeitura do Rio. 2020. Serviços e informações. Disponível em: https://www.rio.rj.gov.br/web/smtr. Acesso em: 13.05.2020.

SECRETARIA MUNICIPAL DE URBANISMO - RJ. 1996. SME/4aGLF Região/Ramos. Processo no 02/325405/1996.

SIDRA. 2010. Sistema IBGE de Recuperação Automática - Dados da Amostra. Disponível em: https://sidra.ibge.gov.br/pesquisa/censodemografico/demografico-2010/amostra-resultados-gerais. Acesso em: 05.05.2020.

SILVA, R. A. R. 2001. A crítica comunitarista ao liberalismo. In: TORRES, R. L. Teoria dos direitos fundamentais. Rio de Janeiro: Renovar, pp.197-242.

SMITH, N. 2000. Contornos de uma política espacializada: veículos dos semteto e produção de escala geográfica. In: ARANTES, A. (Org.). O espaço da diferença. Campinas: Papirus, pp. 132-175.

TAYLOR, C. 1997. As fontes do self: a reconstrução da identidade moderna. São Paulo, Loyola.

THUMMA, S.; TRAVIS, D. 2007. Beyond Megachurch Myths: What Can Be Learned from America's Largest Churches. San Francisco: Jossey Bass Publishers.

TROUILLOT, M.-R. 2006. The anthropology of the State in the age of globalization. Current Anthropology, v. 42, n. 1, pp. 125-138.

URBS CURITIBA. 2020. Urbs em números - Transporte coletivo urbano e Equipamentos urbanos (2019). Disponível em: https://www.urbs.curitiba.pr.gov.br/institucional/urbs-em-numeros. Acesso em: 12.05 .2020 .

USARSKI, F. 2012. A mercantilização do dharma como desafio para a pesquisa sobre o Budismo no Brasil - reflexões sistemáticas. In: VILHENA, M. A.; 
PASSOS, J. D. (Orgs.). Religião e consumo: relações e sentimentos. São Paulo, Paulinas.

WILFORD, Justin. 2012. Sacred Subdivisions: the postsuburban transformation of American evangelicalism. Nova York: NYU Press. 